\title{
Synergistic Antibacterial Potentials of Ocimum gratissimum, Honey and Ciprofloxacin against some Multiple Antibiotic-Resistant Bacteria Isolated from Stool Samples
}

\author{
Oluwatoyosi Ezekiel OLAWALE ${ }^{*}$, Olubukola OLUSOLA-MAKINDE and \\ Muftau Kolawole OLADUNMOYE
}

Department of Microbiology, Federal University of Technology, Akure, Ondo State, Nigeria

('Corresponding author's e-mail: toysyma@yahoo.com)

Received: 27 November 2019, Revised: 1 May 2020, Accepted: 30 June 2020

\begin{abstract}
This study investigated the synergistic antibacterial potentials of Ocimum gratissimum $(O$. gratissimum) leaf acetone extract, honey, and ciprofloxacin against some multiple antibiotic-resistant bacteria. Multiple antibiotic-resistant bacterial isolates from stool samples of diarrhea patients and their typed cultures were subjected to inhibitory assay by mixtures of extract and honey, extract and ciprofloxacin, honey and ciprofloxacin, and extract, honey and ciprofloxacin using tube dilution method. Killing rate and mechanisms of action of the mixtures on the susceptible pathogens were determined. The multiple antibiotic resistance indices of the test organisms (MARI) ranged from 0.7 to 1.0. Extract, honey, and ciprofloxacin mixture at ratio 1:1:1 exerted the lowest minimum inhibitory concentration on $E$. coli, $P$. aeruginosa ATCC 10145, E. coli ATCC 25922, and S. typhi ATCC 14028 at $1.56 \times 10^{-3} \mathrm{mg} / \mathrm{mL}$ compared with ciprofloxacin $\left(3.13 \times 10^{-3} \mathrm{mg} / \mathrm{mL}\right)$. Highest potassium, sodium, and protein leakage was induced by extract and honey mixture $(97.4 \mathrm{cmol} / \mathrm{g})$ in $E$. coli, extract, honey, and ciprofloxacin mixture $(65.2 \mathrm{cmol} / \mathrm{g})$ in $B$. cereus, and extract, honey, and ciprofloxacin mixture $(21.6 \mathrm{mg} / \mathrm{mL})$ in $B$. cereus, respectively. Extract, honey, and ciprofloxacin mixture exerted highest killing rate on B. cereus after $24 \mathrm{~h}$ $\left(1.3 \times 10^{1} \mathrm{cfu} / \mathrm{mL}\right)$. These findings revealed a high synergistic antibacterial potential of $O$. gratissimum leaf acetone extract, honey, and ciprofloxacin against multiple drug-resistant bacteria, thus, implying their potential use in diarrhea treatment.
\end{abstract}

Keywords: Synergism, Antibacterial, Ocimum gratissimum L., Honey, Ciprofloxacin

\section{Introduction}

Antibacterial agents are chemical substances produced by living organisms or plants that can kill or inhibit the growth of bacteria [1]. The use of antibacterial agents, especially antibiotics, in the treatment of diarrhea has led to a discussion about the use of antibiotics in human medicine, due to the development of resistance to antibiotics in bacteria [2]. Therefore, it is very essential to monitor the resistance pattern of antibiotics in human pathogens. Since there has been increase in the number of multiple drug-resistant strains of bacteria causing diarrhea, and this has attracted public health concern, it is important to investigate the potential of combination therapy $[2,3]$.

Although plant products have been reported as alternative antibacterial agents in the treatment of multiple drug-resistant bacterial infections, there is a need for a combination of antibacterial agents to enhance the efficiency and improve the effectiveness of antibacterial therapy [3]. A combination of 2 or more antibacterial agents may result in synergism, additive, indifference, or antagonism. Greater 
antibacterial activity can be achieved when 2 drugs are combined. When there is synergism, microbial inhibition is achieved at lower concentration than when used alone [2].

Ocimum gratissimum L. belongs to a group of plants known as spices in the family of Lamiaceae. It is commonly found in the tropical areas of Africa and India [3]. In Nigeria, it can be found on the savannah and in coastal areas. Because of its sweet scent and pleasant aroma, it is commonly called "scent leaf" in Nigeria [4]. In Nigerian communities, the plant is traditionally used in the treatment of gastrointestinal infections such as diarrhea and dysentery [5]. It is also used in the treatment of skin infections, wounds, ulcers, headaches, insect bites, nasal bleeding, measles, and diabetes [6]. $O$. gratissimum has been reported to be active against several species of bacteria due to its possession of phytochemicals such as phenol, flavonoid, alkaloid, steroid, saponin, and tannin [6].

Honey is a natural food of very high nutritive value which is obtained when the nectar and sweet deposits from plants are gathered and stored in the honeycombs of honeybees [7]. Honey is well recognized for its antibacterial activity, which was first reported in 1892 . Honey has been used for the treatment of wound infection, respiratory ailment, gastrointestinal disorder, and other various diseases [8]. Honey has been reported to have inhibitory properties against many species of bacteria, such as Escherichia coli, Shigella dysentriae, Staphylococcus aureus, Bacillus cereus, and Salmonella spp [9].

The synergistic antibacterial activities of mixtures of $O$. gratissimum leaf extracts with other plants and $O$. gratissimum leaf extracts with antibiotics have been documented in earlier studies [5,10,11]. The mixtures of honey and antibiotics have been reported for synergistic effects against species of bacteria [12]. However, little or no study has revealed the antibacterial properties of a combination of $O$. gratissimum and honey. Therefore, this study aims to investigate the synergistic antibacterial potentials of mixtures of $O$. gratissimum leaf acetone extract, honey, and ciprofloxacin against some multiple antibiotic-resistant bacteria isolated from the stool samples of diarrhea patients in Ondo State, Nigeria.

\section{Materials and methods}

\section{Ethical approval}

The ethical approval to carry out this study was issued by Ondo State Health Research Ethics Committee, Ministry of Health, Ondo state, Nigeria.

\section{Collection of plant material}

The $O$. gratissimum leaves were collected from Falegbe farm, Akure, Ondo State, Nigeria. It was authenticated by Mr. Adejobi from the Department of Crop, Soil and Pest Management, School of Agriculture and Agricultural Technology, Federal University of Technology Akure, (FUTA) Ondo State, Nigeria.

\section{Collection of honey samples}

The honey used for this study was purchased from Nectar Honey Farm. The honey was collected into sterile containers and transported to the Microbiology Laboratory, FUTA.

\section{Collection of stool samples}

A total of 60 stool samples were collected from diarrhea patients attending specialist hospitals in Akure, Ondo State, Nigeria. Non-diarrhea patients were excluded. These samples were collected into sterile universal bottles and transported to the Microbiology Laboratory, FUTA.

\section{Isolation of bacteria}

Bacteria were isolated from the stool samples and identified using the method described by Abhishek et al. [13]. The agar used included: Nutrient Agar, MacConkey Agar, and Salmonella Shigella Agar. All media were prepared according to the manufacturer's specification. Culture media, diluents, and water were sterilized in autoclave at $121{ }^{\circ} \mathrm{C}$ for $15 \mathrm{~min}$, while glass wares were sterilized using an oven at $160^{\circ} \mathrm{C}$ for $2 \mathrm{~h}[13]$. 


\section{Collection of typed cultures}

Typed bacteria that correlated with clinical bacterial isolates were collected from the Federal Institute of Industrial Research Oshodi (FIIRO), Lagos State, Nigeria. The bacterial isolates were: E. coli ATCC 25922, P. aeruginosa ATCC 10145, S. aureus NTCC 6571, and S. typhi ATCC 10145.

\section{Extraction of plant material}

$100 \mathrm{~g}$ of the grounded leaves was weighed and soaked in $1,000 \mathrm{~mL}$ of the extraction solvent (acetone) for $72 \mathrm{~h}$ at room temperature and stirred occasionally in order to obtain the extract. The residue was filtered using Muslin cloth to obtain the filtrate, and then was further purified by filtration through Whatman No 1 filter paper under aseptic conditions. The filtrate was evaporated to dryness using a rotary evaporator, and then stored in a refrigerator at $4{ }^{\circ} \mathrm{C}$ until required for use [14].

\section{Phytochemical screening}

The extract and honey were screened for alkaloids, tannin, saponin, phlobatannin, steroid, flavonoid, terpenoid, and cardiac glycoside, and the quantity of the constituents was determined using the method described by Ladipo et al. [14].

\section{Standardization of inoculum}

A standard inoculum from a $24 \mathrm{~h}$ culture was prepared by suspension in a nutrient broth and adjustment with sterile normal saline until the turbidity matched a 0.5 MacFarland [15].

\section{Antibiotic susceptibility assay}

The Kirby-Bauer disc diffusion method was used to determine the effect of standard antibiotics on the bacterial isolates, as described by Willey et al. [1]. Clinical Laboratory Standardization Institute [16] was used to determine the resistant strains of the isolated bacteria, and the multiple antibiotic resistant index was calculated using the formula: $a / b$; where $a=$ number of antibiotics that showed resistance to the bacterial isolates and $b=$ total number of antibiotics used.

\section{Screening for antibacterial activity}

The antibacterial activities of extract and honey were evaluated using the agar well diffusion method, as described by Ubafie and Ejale [15]. The prepared Muller Hinton agar plates were swabbed with suspension of the bacterial isolates using sterile swab sticks. The extract was reconstituted using Dimethyl sulfoxide (DMSO) to obtain the concentration of the extract ( $\mathrm{mg} / \mathrm{mL})$. Wells of approximately $6 \mathrm{~mm}$ in diameter were made on the surfaces of the already streaked Petri dishes using a sterile cork borer. Wells were filled with $0.1 \mathrm{~mL}$ of the extract, honey, ciprofloxacin, and sterile distilled water using a micro pipette. Ciprofloxacin served as the standard positive control, while distilled water was used as the negative control. The extract was tested at $100 \mathrm{mg} / \mathrm{mL}$ while honey was tested at $200 \mathrm{mg} / \mathrm{mL}$. The plates were incubated at $37^{\circ} \mathrm{C}$ for $24 \mathrm{~h}$. The zones of inhibition were measured.

\section{Determination of minimum inhibitory concentration (MIC)}

The minimum inhibitory concentration (MIC) of the extract, honey, ciprofloxacin, and their mixtures was determined using the broth dilution method, as described by Willey et al. [1]. The MIC was determined at varying concentrations. The concentrations were: $200,100,50,25,12.5,6.25,3.125,0.50$, $0.25,0.125,0.0625,0.0313$, and $0.0156 \mathrm{mg} / \mathrm{mL}$. The tubes were examined for visible growth, and the lowest concentration that was able to inhibit the growth of bacteria when compared with the control was noted as the MIC.

\section{Screening for synergistic activity}

Screening for synergistic antibacterial activity was carried out using the tube dilution method, as described by Omoya and Ajayi [2]. The same concentration and volume of extract and honey, extract and ciprofloxacin, honey and ciprofloxacin, and extract, honey and ciprofloxacin was introduced into tubes 
containing the test organisms. The minimum inhibitory concentrations of the combinations was noted. The activity was conducted to show synergism, additive, antagonism, or indifference.

\section{Calculation of fractional inhibitory concentration (FIC)}

The FIC of the 4 combinations was determined using the standard checkerboard method, as described by Omoya and Ajayi [2]. The FIC was calculated using the equation: FIC = MIC of combined/MIC of single, $\sum$ FIC $=$ FIC of A + FIC of B.

Synergism is defined as FIC $\leq 0.5$, additive as FIC $>0.5$ and $\leq 1$, indifference as FIC $>1$ and $\leq 2$, and antagonism is defined as FIC $>2$.

\section{Determination of sodium and potassium leakage}

Half a milliliter each of the standardized pre-cultured bacterial isolates that were susceptible to the synergistic combinations was added to $4.5 \mathrm{~mL}$ of the prepared concentration $(100 \mathrm{mg} / \mathrm{mL})$ of each of the 4 combinations, and then incubated for $18 \mathrm{~h}$. The solution was centrifuged at 7,000 rpm, and the supernatant was analyzed using a flame photometer at 589 and $766 \mathrm{~nm}$ for sodium and potassium ion leakage, respectively. The sodium and potassium ion leakage was determined using the method described by Akinyemi and Ogundare [17] with slight modification.

Calculation:

Sodium ion $\left(\mathrm{Na}^{+}\right)($centimole/gram $)=$absorbance $/ 230 \times 100$

Potassium ion $\left(\mathrm{K}^{+}\right)($centimole/gram $)=$absorbance $/ 390 \times 100$

\section{Determination of killing rate of bacterial isolates}

The rate of killing of the bacteria that were susceptible to synergistic combinations was determined using the method of Akinyemi and Ogundare [17]. Five $\mathrm{mL}$ of the standardized broth culture was introduced into the minimum inhibitory concentrations of each of the mixtures. The suspension was mixed and then plated using the pour plate method at $0,2,4,6$, and $24 \mathrm{~h}$. The plates were incubated at 37 ${ }^{\circ} \mathrm{C}$ for $24 \mathrm{~h}$, after which observation was made for microbial growth. The numbers of colonies were counted using a digital colony counter.

\section{Data analysis}

Data were analyzed by subjecting to Analysis of Variance (ANOVA), and the means were separated using Duncan's multiple range test at a $95 \%$ level of significance $(\mathrm{p} \leq 0.05)$.

\section{Results and discussion}

Bacteria isolated from stool samples

Bacteria isolated in this study were identified as E. coli, Salmonella spp, S. aureus, S. dysentriae, B. cereus, and $P$. aeruginosa. The multiple antibiotic resistant indices of the isolated bacteria ranged from 0.7 to 1.0 (Figure 1). The multiple antibiotic resistance indices (MARI) observed for the bacterial isolates in this study revealed a trend of resistance of the bacteria to conventional drugs. Similar results were observed by Onuoha [18], with MARI $>0.2$ observed in B. cereus, S. aureus, E. coli, and Salmonella spp. Onuoha [18] reported that indiscriminate use of antibiotics may favor the emergence of resistant strains of bacteria.

\section{Qualitative and quantitative phytochemical constituents}

The phytochemical screening of $O$. gratissimum leaf acetone extract and honey revealed the presence of saponin, steroid, flavonoid, and cardiac glycoside. However, O. gratissimum leaf acetone extract also revealed the presence of tannin, terpenoid, and phenol, which are absent in honey (Table 1). Saponin had the highest phytochemical constituents in O. gratissimum leaf acetone extract $(42.50 \pm 0.32$ $\mathrm{mg} / \mathrm{g}$ ), while cardiac glycoside had the highest in honey with $6.98 \pm 0.03 \mathrm{mg} / \mathrm{g}$ (Table 2). This is in line with the reports of Nwankwo et al. [8] and Ladipo et al. [14], that $O$. gratissimum leaf extracts and honey 
contain the above phytochemicals. The flavonoid obtained in the plant extract and honey is believed to act by binding with soluble proteins and the bacterial cell wall, thereby disrupting their membrane integrity [19].

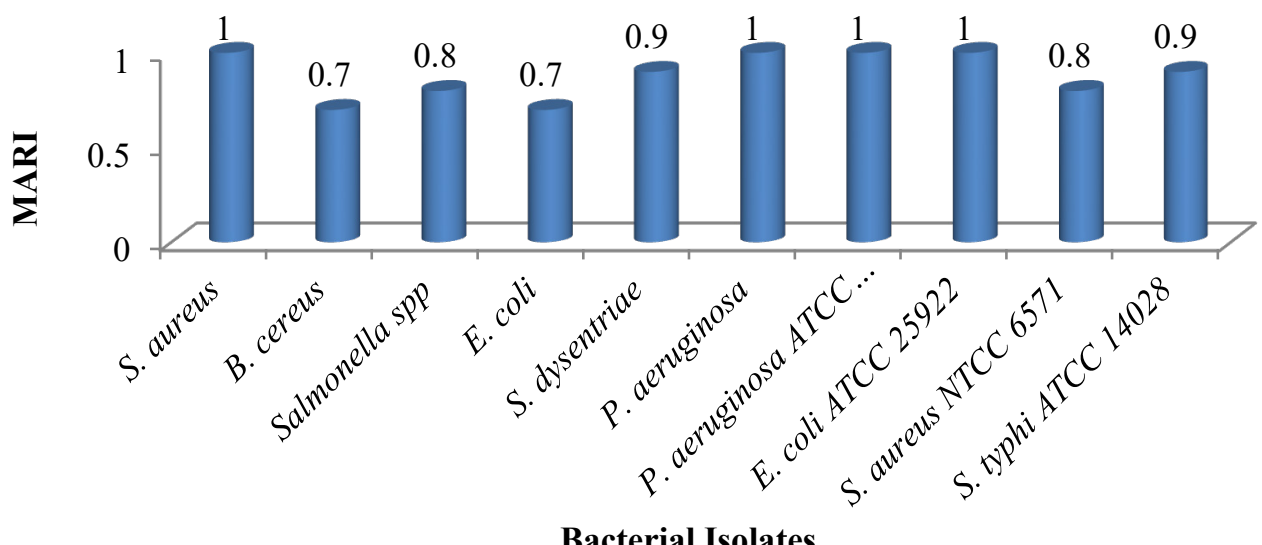

Figure 1 Multiple antibiotic resistant indices of bacterial isolates.

Table 1 Qualitative phytochemical screening of $O$. gratissimum leaf acetone extract and honey.

\begin{tabular}{lll}
\hline Constituent & Acetone Extract & Honey \\
\hline Saponin & + & + \\
Tannin & + & - \\
Steroids & + & + \\
Terpenoids & + & - \\
Flavonoids & + & + \\
Alkaloids & - & - \\
Phlebotannin & - & - \\
Phenol & + & - \\
Cardiac Glycoside & & + \\
Keller kiliani Test & + & - \\
Salkwoski Test & - & + \\
Lieberman Test & + & + \\
\hline
\end{tabular}

Keys: + = present, - = absent.

Table 2 Quantitative phytochemical screening of $O$. gratissimum leaf acetone extract and honey (mg/g)

\begin{tabular}{lll}
\hline Constituent & Acetone extract & Honey \\
\hline Saponin & $42.50 \pm 0.32^{\mathrm{e}}$ & $1.00 \pm 0.27^{\mathrm{b}}$ \\
Tannin & $1.29 \pm 0.01^{\mathrm{d}}$ & $0.00 \pm 0.00^{\mathrm{a}}$ \\
Steroids & $9.02 \pm 0.02^{\mathrm{f}}$ & $1.07 \pm 0.05^{\mathrm{b}}$ \\
Terpenoids & $28.29 \pm 0.03^{\mathrm{d}}$ & $0.00 \pm 0.00^{\mathrm{a}}$ \\
Flavonoids & $2.62 \pm 0.02^{\mathrm{d}}$ & $0.42 \pm 0.01^{\mathrm{a}}$ \\
Phenol & $21.38 \pm 0.06^{\mathrm{d}}$ & $0.00 \pm 0.00^{\mathrm{a}}$ \\
Cardiac glycoside & $17.43 \pm 0.03^{\mathrm{f}}$ & $6.98 \pm 0.03^{\mathrm{d}}$ \\
\hline
\end{tabular}

Values are represented as mean \pm standard error $(n=2)$ with the same superscript across the row are not significantly different $(\mathrm{p}<0.05)$. 


\section{isolates \\ Antibacterial activity of $\boldsymbol{O}$. gratissimum leaf acetone extract and honey against bacterial}

Acetone extract at $100 \mathrm{mg} / \mathrm{mL}$ displayed the highest zone of inhibition on E. coli $(26.67 \pm 0.33 \mathrm{~mm})$. Also, the highest zone of inhibition by honey was observed in $S$. aureus and P. aeruginosa (14.67 \pm 0.33 $\mathrm{mm}$ ), but resistance to honey was recorded in $S$. dysentriae (Table 3). The results of the antibacterial activities of $O$. gratissimum leaf extracts and honey showed that the plant possesses more potent antibacterial activity than honey. This agreed with the previous studies of Amadi et al. [20], Amengialue et al. [4], Odebisi-Omokanye et al. [19], and Ubafie and Ejale [15], that extracts of O. gratissimum have higher antibacterial potentials against enteric bacteria. This may be attributed to additional secondary metabolites such as tannin, terpenoid, and phenol present in O. gratissimum leaf extracts, but which were found to be absent in honey used in this study.

Comparative minimum inhibitory concentrations of $O$. gratissimum leaf acetone extract, honey, and ciprofloxacin against bacterial isolates

The acetone extract displayed the lowest MIC on $S$. typhi ATCC 14028 at $6.25 \mathrm{mg} / \mathrm{mL}$, and the lowest MIC of honey was observed on E. coli and S. typhi ATCC 14028 at $50 \mathrm{mg} / \mathrm{mL}$. Mixture of $O$. gratissimum leaf acetone extract, honey, and ciprofloxacin at ratio 1:1:1 had the lowest microbial inhibition factor on all the bacterial isolates. The lowest MIC of the combination was observed on E. coli, P. aeruginosa ATCC 10145, E. coli ATCC 25922, and S. typhi ATCC 14028 at $1.56 \times 10^{-3} \mathrm{mg} / \mathrm{mL}$ compared to ciprofloxacin $\left(3.13 \times 10^{-3} \mathrm{mg} / \mathrm{mL}\right)$ (Table 4). The minimum inhibitory concentration observed for the plant extract and honey revealed that plant extracts inhibited the growth of the selected bacteria at lower concentration than honey. This finding agreed with the work of Odebisi-Omokanye et al. [19], that extracts of $O$. gratissimum leaf exhibit lower MIC on enteric pathogens. This indicates that the phytoconstituents present in the plant have higher therapeutic potentials compared to honey. The lowest MIC was recorded in the combination of $O$. gratissimum leaf acetone extract, honey, and ciprofloxacin at $1: 1: 1$. This may be attributed to the combined effect of the antibacterial properties present in the antimicrobial agents [5].

Fractional inhibitory concentration index of mixtures of $O$. gratissimum leaf acetone extract, honey, and ciprofloxacin

The fractional inhibitory concentration index $\left(\mathrm{FIC}_{\text {index }}\right)$ of the 4 different combinations used ranged from 0.125 to 2.0 (Tables 5 - 8). E. coli, Salmonella spp, B. cereus, P. aeruginosa ATCC 10145, and E. coli ATCC 25922 displayed synergistic reactions to the combination of extract and honey with sum of FIC ( $\sum$ FIC) of $0.188,0.188,0.313,0.156$, and 0.156 respectively (Table 5). Synergistic reaction was also observed in combination of extract, honey, and ciprofloxacin against E. coli, B. cereus, P. aeruginosa ATCC 10145, E. coli ATCC 25922, S. aureus NTCC 6571, and S. typhi ATCC 14028 with $\sum$ FIC of 0.5 (Table 8). There was no synergistic reaction in the mixture of extract and honey (Table 7). Mixtures of O. gratissimum leaf acetone extract, honey, and ciprofloxacin; O. gratissimum leaf acetone extract and ciprofloxacin; and $O$. gratissimum leaf acetone extract and honey displayed synergistic interactions on the screened bacteria. This agreed with the studies of Nweze and Eze [21] and Nwankwo et al. [5], who reported synergistic reactions in the combinations of $O$. gratissimum leaf extracts and ciprofloxacin and O. gratissimum leaf extracts and Garcinia kola, respectively. Nwankwo et al. [5] reported that the synergistic reaction could be attributed to the combined effect of the phytochemicals present in $O$. gratissimum leaf acetone extract and honey. In other words, phytochemicals of the plant when combined with antibiotics may cause increase in the biological activity potential of the plant. Bioactive components are believed to disturb the permeability of the cytoplasmic membrane of bacteria and, thereby, facilitate the entry of antimicrobial agents [22]. The combination of honey and ciprofloxacin did not show synergistic interaction on the isolated bacteria. This is not in line with the works of Liu et al. [12], which reported synergistic interaction in the mixture of honey and antibiotics. The non-synergistic effect displayed by the honey and antibiotics mixture may be explained in terms of the MIC of honey compared with antibiotics, leading to difficulty in the reduction of the honey dosage required for synergistic effects. 
Table 3 Antibacterial activity of $O$. gratissimum leaf acetone extract and honey against bacterial isolates (mm).

\begin{tabular}{lll}
\hline Isolate & Acetone extract & Honey \\
\hline S. aureus & $15.33 \pm 0.33^{\mathrm{b}}$ & $14.67 \pm 0.33^{\mathrm{b}}$ \\
B. cereus & $19.00 \pm 0.58^{\mathrm{d}}$ & $10.67 \pm 0.33^{\mathrm{b}}$ \\
S. typhi & $17.33 \pm 0.33^{\mathrm{d}}$ & $10.33 \pm 0.33^{\mathrm{b}}$ \\
S. dysentriae & $21.00 \pm 0.58^{\mathrm{c}}$ & $0.00 \pm 0.00^{\mathrm{a}}$ \\
E. coli & $26.67 \pm 0.33^{\mathrm{d}}$ & $11.67 \pm 0.33^{\mathrm{b}}$ \\
P. aeruginosa & $17.67 \pm 0.88^{\mathrm{d}}$ & $14.67 \pm 0.33^{\mathrm{c}}$ \\
P. aeruginosa ATCC 10145 & $12.33 \pm 0.33^{\mathrm{c}}$ & $15.00 \pm 0.00^{\mathrm{d}}$ \\
E. coli ATCC 25922 & $21.00 \pm 0.00^{\mathrm{c}}$ & $14.33 \pm 0.33^{\mathrm{b}}$ \\
S. aureus NTCC 6571 & $11.00 \pm 0.00^{\mathrm{b}}$ & $14.67 \pm 0.33^{\mathrm{c}}$ \\
S. typhi ATCC 1402 & $21.33 \pm 0.66^{\mathrm{c}}$ & $15.33 \pm 0.33^{\mathrm{b}}$ \\
\hline
\end{tabular}

Values are represented as mean \pm standard error $(n=3)$ with the same superscript across the row are not significantly different $(\mathrm{p}<0.05)$.

Table 4 Comparative minimum inhibitory concentrations $(\mathrm{mg} / \mathrm{mL})$ of $O$. gratissimum leaf acetone extract, honey, and ciprofloxacin against bacterial isolates.

\begin{tabular}{llllllll}
\hline Isolates & $\mathbf{A}$ & $\mathbf{B}$ & $\mathbf{C}$ & $\mathbf{A}+\mathbf{B}$ & $\mathbf{A}+\mathbf{C}$ & $\mathbf{B}+\mathbf{C}$ & $\mathbf{A}+\mathbf{B}+\mathbf{C}$ \\
\hline $\begin{array}{l}\text { Staphylococcus } \\
\text { aureus }\end{array}$ & 25 & 100 & $6.25 \times 10^{-3}$ & 12.5 & $6.25 \times 10^{-3}$ & $6.25 \times 10^{-3}$ & $1.25 \times 10^{-2}$ \\
$\begin{array}{l}\text { Bacillus cereus } \\
\text { Salmonella spp }\end{array}$ & 50 & 100 & $6.25 \times 10^{-3}$ & 6.25 & $6.25 \times 10^{-3}$ & $6.25 \times 10^{-3}$ & $3.13 \times 10^{-3}$ \\
$\begin{array}{l}\text { Shigella dysentriae } \\
\text { Escherichia coli }\end{array}$ & 12.5 & $\mathrm{R}$ & $6.25 \times 10^{-3}$ & 12.5 & $6.25 \times 10^{-3}$ & $6.25 \times 10^{-3}$ & $1.25 \times 10^{-2}$ \\
$\begin{array}{l}\text { Pseudomonas } \\
\text { aeruginosa }\end{array}$ & 12.5 & 50 & $6.25 \times 10^{-3}$ & 3.125 & $3.13 \times 10^{-3}$ & $6.25 \times 10^{-3}$ & $1.56 \times 10^{-3}$ \\
$\begin{array}{l}\text { Pseudomonas } \\
\text { aeruginosa ATCC }\end{array}$ & 25 & 200 & $6.25 \times 10^{-3}$ & 25 & $6.25 \times 10^{-3}$ & $6.25 \times 10^{-3}$ & $6.25 \times 10^{-3}$ \\
$\begin{array}{l}\text { 10145 } \\
\begin{array}{l}\text { Escherichia coli } \\
\text { ATCC 25922 }\end{array}\end{array}$ & 25 & 100 & $3.13 \times 10^{-3}$ & 3.125 & $1.56 \times 10^{-3}$ & $6.25 \times 10^{-3}$ & $1.56 \times 10^{-3}$ \\
$\begin{array}{l}\text { Staphylococcus } \\
\text { aureus } \text { NTCC 6571 }\end{array}$ & 25 & 100 & $6.25 \times 10^{-3}$ & 12.5 & $6.25 \times 10^{-3}$ & $6.25 \times 10^{-3}$ & $3.13 \times 10^{-3}$ \\
$\begin{array}{l}\text { Salmonella typhi } \\
\text { ATCC 14028 }\end{array}$ & 6.25 & 50 & $3.13 \times 10^{-3}$ & 3.125 & $1.56 \times 10^{-3}$ & $6.25 \times 10^{-3}$ & $1.56 \times 10^{-3}$ \\
\hline
\end{tabular}

Keys: $\mathrm{A}=O$. gratissimum leaf acetone extract, $\mathrm{B}=$ Honey, and $\mathrm{C}=$ Ciprofloxacin and $\mathrm{R}=$ Resistance. 
Table 5 Fractional inhibitory concentration index of combined $O$. gratissimum leaf acetone extract and honey against bacterial isolates.

\begin{tabular}{|c|c|c|c|c|}
\hline Isolates & FIC $_{E}$ & $\mathrm{FIC}_{\mathrm{H}}$ & $\sum$ FIC & Remark \\
\hline S. aureus & 0.500 & 0.125 & 0.625 & Additive \\
\hline B. cereus & 0.125 & 0.063 & 0.188 & Synergistic \\
\hline Salmonella spp & 0.125 & 0.063 & 0.188 & Synergistic \\
\hline S. dysentriae & 1.000 & 0.000 & 1.000 & Additive \\
\hline E. coli & 0.250 & 0.063 & 0.313 & Synergistic \\
\hline P. aeruginosa & 1.000 & 0.125 & 1.013 & Additive \\
\hline P. aeruginosa ATCC 10145 & 0.125 & 0.031 & 0.156 & Synergistic \\
\hline E. coli ATCC 25922 & 0.125 & 0.031 & 0.156 & Synergistic \\
\hline S. aureus NTCC 6571 & 0.500 & 0.125 & 0.625 & Additive \\
\hline S. typhi ATCC 14028 & 0.500 & 0.063 & 0.563 & Additive \\
\hline
\end{tabular}

Table 6 Fractional inhibitory concentration index of combined O. gratissimum leaf acetone extract and ciprofloxacin against bacterial isolates.

\begin{tabular}{|c|c|c|c|c|}
\hline Isolates & $\mathrm{FIC}_{\mathrm{E}}$ & $\mathrm{FIC}_{\mathrm{A}}$ & $\sum$ FIC & Remark \\
\hline S. aureus & 0.000 & 1.000 & 1.000 & Additive \\
\hline B. cereus & 0.000 & 1.000 & 1.000 & Additive \\
\hline Salmonella spp & 0.000 & 1.000 & 1.000 & Additive \\
\hline S. dysentriae & 0.000 & 1.000 & 1.000 & Additive \\
\hline E. coli & 0.000 & 0.500 & 0.500 & Synergistic \\
\hline P. aeruginosa & 0.000 & 1.000 & 1.000 & Additive \\
\hline P. aeruginosa ATCC 10145 & 0.000 & 0.500 & 0.500 & Synergistic \\
\hline E. coli ATCC 25922 & 0.000 & 0.500 & 0.500 & Synergistic \\
\hline S. aureus NTCC 6571 & 0.000 & 1.000 & 1.000 & Additive \\
\hline S. typhi ATCC 14028 & 0.000 & 0.500 & 0.500 & Synergistic \\
\hline
\end{tabular}

Table 7 Fractional inhibitory concentration index of combined honey and ciprofloxacin against bacteria isolated from stool samples and their typed cultures.

\begin{tabular}{lcccc}
\hline Isolates & FIC $_{\mathbf{H}}$ & FIC $_{\mathbf{A}}$ & $\sum_{\text {FIC }}$ & Remark \\
\hline S. aureus & 0.000 & 1.000 & 1.000 & Additive \\
B. cereus & 0.000 & 1.000 & 1.000 & Additive \\
Salmonella spp & 0.000 & 1.000 & 1.000 & Additive \\
S. dysentriae & 0.000 & 1.000 & 1.000 & Additive \\
E. coli & 0.000 & 1.000 & 1.000 & Additive \\
$P$. aeruginosa & 0.000 & 1.000 & 1.000 & Additive \\
$P$. aeruginosa ATCC 10145 & 0.000 & 1.000 & 1.000 & Additive \\
E. coli ATCC 25922 & 0.000 & 1.000 & 1.000 & Additive \\
S. aureus NTCC 6571 & 0.000 & 1.000 & 1.000 & Additive \\
S. typhi ATCC 14028 & 0.000 & 1.000 & 1.000 & Additive \\
\hline
\end{tabular}


Table 8 Fractional inhibitory concentration index of combined O. gratissimum leaf acetone extract, honey, and ciprofloxacin against bacterial isolates.

\begin{tabular}{llllll}
\hline Isolates & FIC $_{\mathbf{E}}$ & FIC $_{\mathbf{H}}$ & FIC $_{\mathbf{A}}$ & $\sum_{\text {FIC }}$ & Remark \\
\hline S. aureus & 0.000 & 0.000 & 2.000 & 2.000 & Indifference \\
B. cereus & 0.000 & 0.000 & 0.500 & 0.500 & Synergistic \\
Salmonella spp & 0.000 & 0.000 & 1.000 & 1.000 & Additive \\
S. dysentriae & 0.000 & 0.000 & 2.000 & 2.000 & Indifference \\
E. coli & 0.000 & 0.000 & 0.500 & 0.500 & Synergistic \\
P. aeruginosa & 0.000 & 0.000 & 1.000 & 1.000 & Additive \\
P. aeruginosa ATCC 10145 & 0.000 & 0.000 & 0.500 & 0.500 & Synergistic \\
E. coli ATCC 25922 & 0.000 & 0.000 & 0.500 & 0.500 & Synergistic \\
S. aureus NTCC 6571 & 0.000 & 0.000 & 0.500 & 0.500 & Synergistic \\
S. typhi ATCC 14028 & 0.000 & 0.000 & 0.500 & 0.500 & Synergistic \\
\hline
\end{tabular}

Keys: FIC $=$ Fractional inhibitory concentration, $\mathrm{E}=O$. gratissimum leaf acetone extract, $\mathrm{H}=$ honey, $\mathrm{A}=$ ciprofloxacin, $\sum=$ sum.

Protein leakage of bacterial isolates by mixtures of $\boldsymbol{O}$. gratissimum leaf acetone extract, honey and ciprofloxacin

Protein leakage of bacteria which showed synergistic reaction to mixtures of extract and honey, extract and ciprofloxacin, and extract, honey, and ciprofloxacin is presented in Figures 2(a) to 2(c). The highest protein leakage was observed in E. coli ATCC 25922 by O. gratissimum leaf acetone extract, honey, and ciprofloxacin mixture at $21.6 \mathrm{mg} / \mathrm{mL}$ (Figure 2(c)). Both Gram positive and Gram negative bacteria leaked protein into the growing medium in variable values. Despite the complexity of the cell composition of Gram negative bacteria, the highest protein molecules were leaked from the cell wall of Gram negative bacteria compared to Gram positive bacteria. This opposes the works of Oladunmoye et al. [23], that Gram positive bacteria leaked higher protein values than Gram negative bacteria. This may be due to variation in the concentrations of active compounds present in the mixtures of extract, honey, and ciprofloxacin, extract and ciprofloxacin, and extract and honey [24]. The presence of certain biomolecules in a certain mixture may increase antimicrobial efficacy and, consequently, induce higher protein leakage [22].

\section{Amount of sodium and potassium ions $(\mathrm{cmol} / \mathrm{g})$ released by bacterial isolates}

$O$. gratissimum leaf acetone extract and honey combination induced the highest potassium leakage in $E$. coli with $97.4 \mathrm{cmol} / \mathrm{g}$, while the highest sodium leakage was observed in $B$. cereus by the combination of $O$. gratissimum leaf acetone extract, honey, and ciprofloxacin at $65.2 \mathrm{cmol} / \mathrm{g}$ (Table 9). The mixtures of extract, honey, and ciprofloxacin, extract and ciprofloxacin, and extract and honey exerted antibacterial effects through the release of sodium and potassium ions from the membrane of the assayed bacteria. This is at equivalence with the findings of Akinyemi and Ogundare [3], that extracts of Anthocleista djalonensis induced antibacterial effects through the leakage of intracellular materials, which is evident in its membrane-damaging action. Oladunmoye et al. [23] also submitted that ethanol extract of Cassia occidentalis had lytic effects on pathogenic microorganisms, as intracellular ions were leaked from their cells. Sodium and potassium ions have been known to affect the osmotic balance in the cell, and their leakage might cause cell lysis, which may eventually lead to the death of the cell. The release of these ions must have been a complex series of events taking place in the cell following the uptake of bioactive compounds from the mixtures and the immobility of the lipid membrane [1]. 


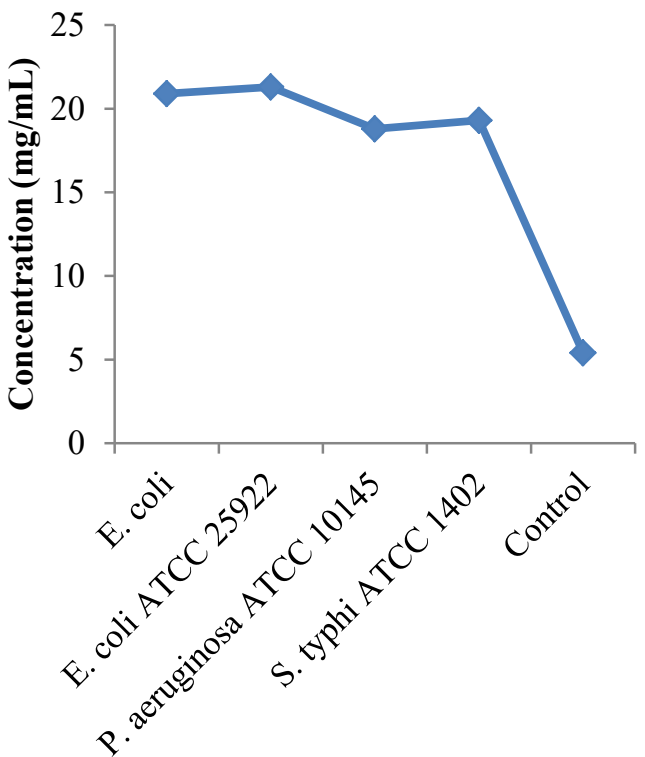

Bacterial Isolates

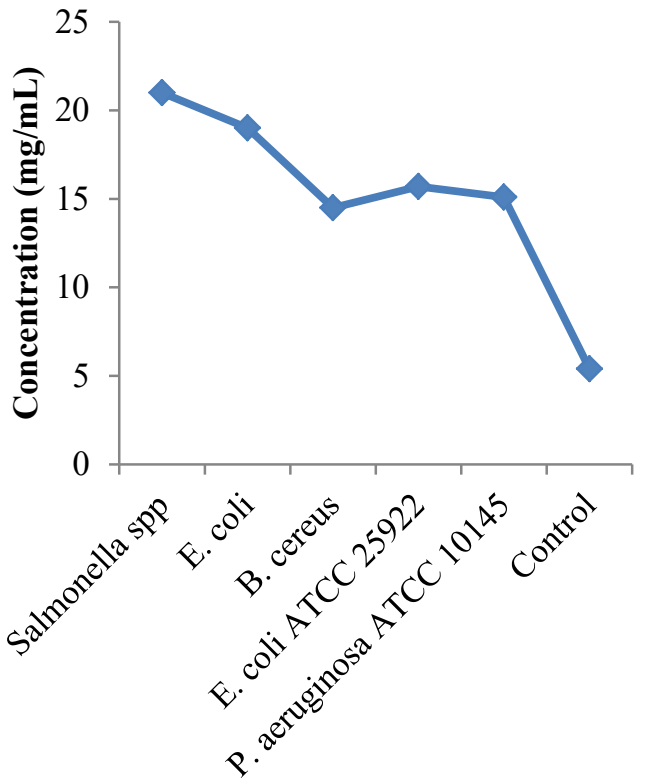

Bacterial Isolates

(a)

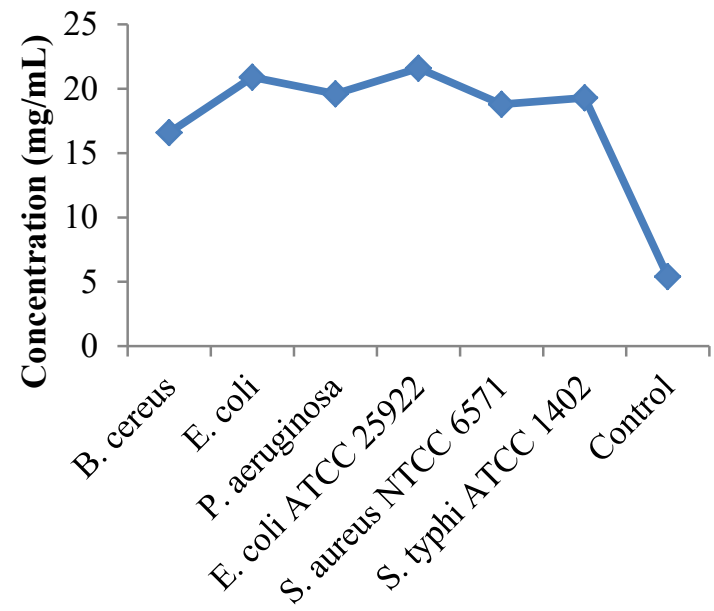

Bacterial Isolates

(c)

Figure 2 (a) $=$ Protein leakage of bacterial isolates by mixture of $O$. gratissimum leaf acetone extract and ciprofloxacin; (b) = Protein leakage of bacterial isolates by mixture of $O$. gratissimum leaf acetone extract and honey; (c) = Protein leakage of bacterial isolates by mixture of $O$. gratissimum leaf acetone extract, honey and ciprofloxacin; Control = Bradford reagent without organism. 
Killing rate of bacterial isolates by mixtures of $O$. gratissimum leaf acetone extract, honey, and ciprofloxacin

The killing rate of $B$. cereus, Salmonella spp, E. coli, and all the typed cultures is presented in Figures 3(a) to $3(\mathbf{g})$. The highest killing rate was observed in $B$. cereus at $24 \mathrm{~h}$ of exposure to $O$. gratissimum leaf acetone extract, honey, and ciprofloxacin mixture with $1.3 \times 10^{1} \mathrm{cfu} / \mathrm{mL}$ (Figure 3(a)). The inhibitory effect of the synergistic mixtures revealed reduction in the number of bacteria present at each hour with increase in the time of exposure of the bacteria to the mixtures $\left(1.3 \times 10^{1} \mathrm{cfu} / \mathrm{mL}\right)$. However, there was no bactericidal effect exhibited by the mixtures at MIC. This corresponds with the result of Akinyemi and Ogundare [17], where they reported the killing rate of tested organisms at 50 $\mathrm{mg} / \mathrm{mL}$ of extracts of Anthocleista djalonensis. This may be because, at MICs, the mixtures were not able to completely disrupt the cell wall of the screened bacteria [25].

Table 9 Amount of sodium and potassium ions $(\mathrm{cmol} / \mathrm{g})$ released by bacterial isolates.

\begin{tabular}{|c|c|c|c|c|c|c|}
\hline \multirow[t]{2}{*}{ Isolate } & \multicolumn{2}{|c|}{ Extract + Ciprofloxacin } & \multicolumn{2}{|c|}{ Extract + Honey } & \multicolumn{2}{|c|}{$\begin{array}{c}\text { Extract + Honey }+ \\
\text { Ciprofloxacin }\end{array}$} \\
\hline & $\mathrm{Na}^{+}$ & $\mathbf{K}^{+}$ & $\mathrm{Na}^{+}$ & $\mathbf{K}^{+}$ & $\mathrm{Na}^{+}$ & $\mathbf{K}^{+}$ \\
\hline B. cereus & ND & ND & 48 & 74.4 & 65.2 & 74.4 \\
\hline Salmonella spp & ND & ND & 48 & 72 & ND & ND \\
\hline E. coli & 26.1 & 72 & 35 & 97.4 & 35 & 69.2 \\
\hline S. aureus NTCC 6571 & ND & ND & ND & ND & 22 & 72 \\
\hline E. coli ATCC 25922 & 17.4 & 69 & 39 & 74.4 & 17.4 & 74.4 \\
\hline P. aeruginosa ATCC 10145 & 26.1 & 74.4 & 52.2 & 77 & 26 & 72 \\
\hline S. typhi ATCC 14028 & 22 & 74.4 & ND & ND & 35 & 72 \\
\hline Control & 4.35 & 13 & 8.7 & 23 & 8.5 & 23 \\
\hline
\end{tabular}

Keys: $\mathrm{ND}=$ Not determined, $\mathrm{Na}^{+}=$Sodium ion, $\mathrm{K}^{+}=$Potassium ion, control $=$broth + mixture 


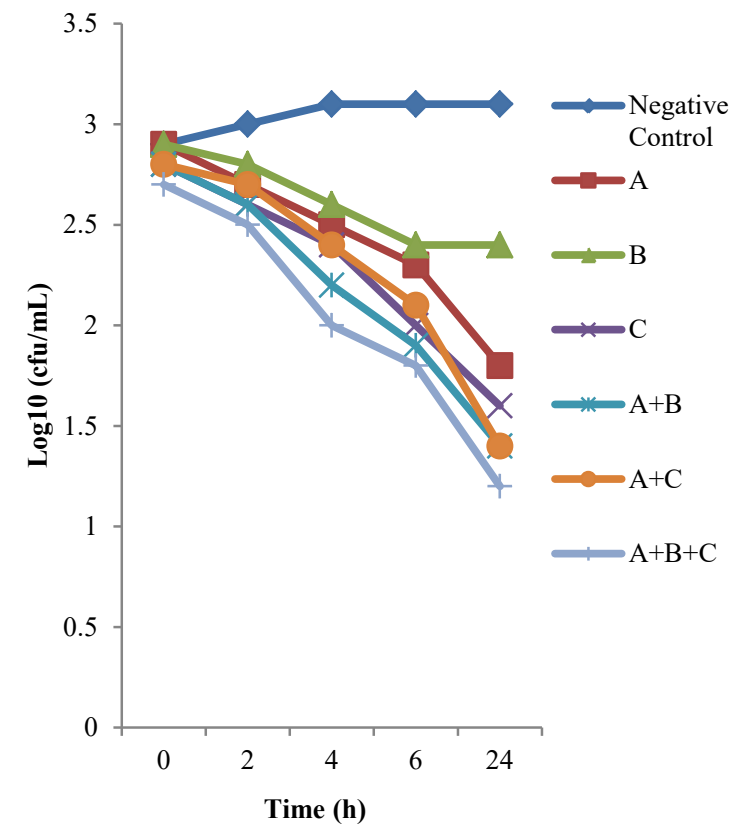

(a)

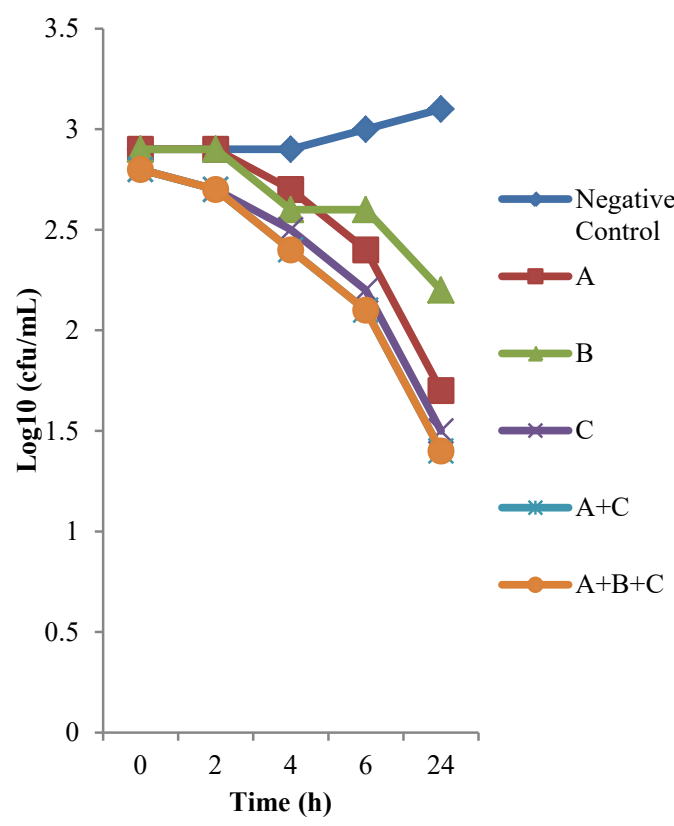

(c)

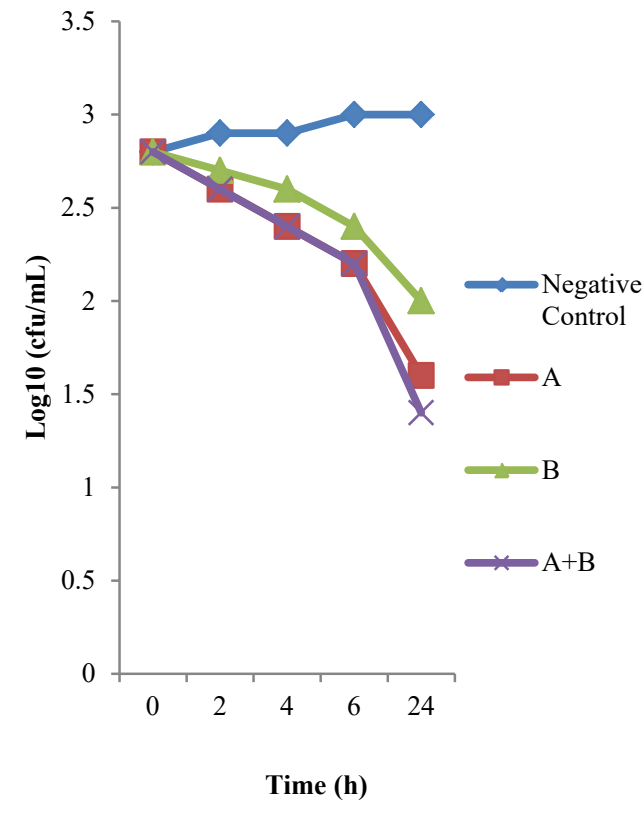

(b)

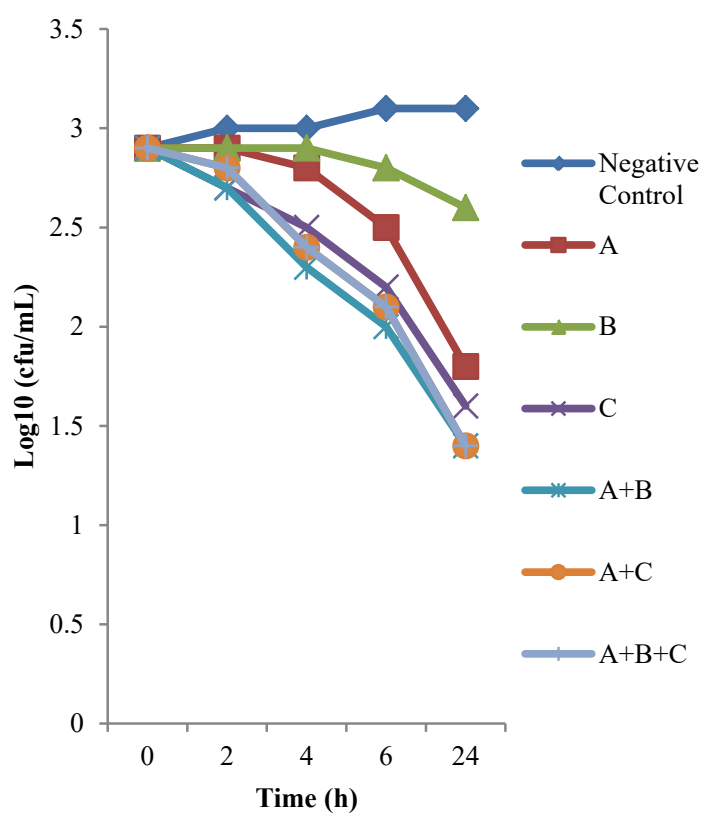

(d) 


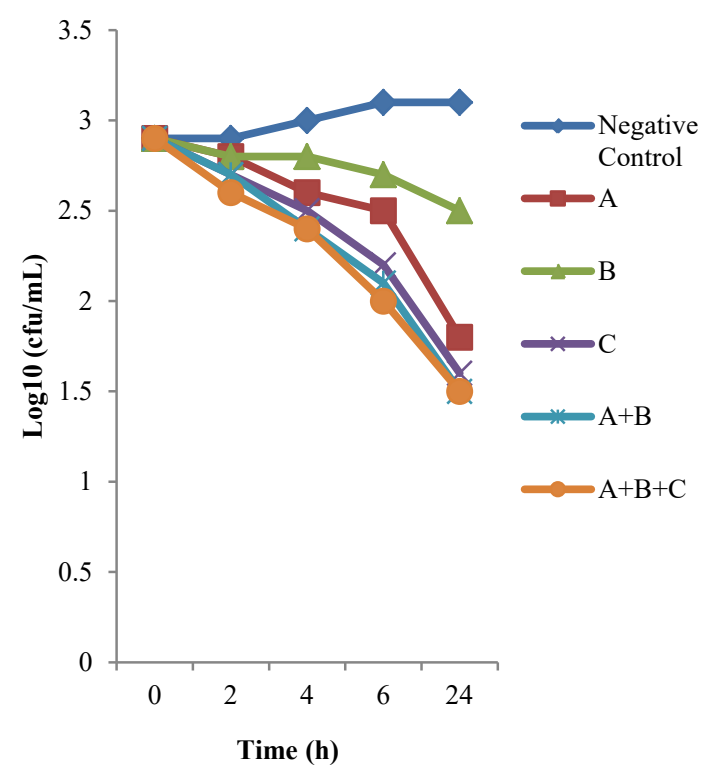

(e)

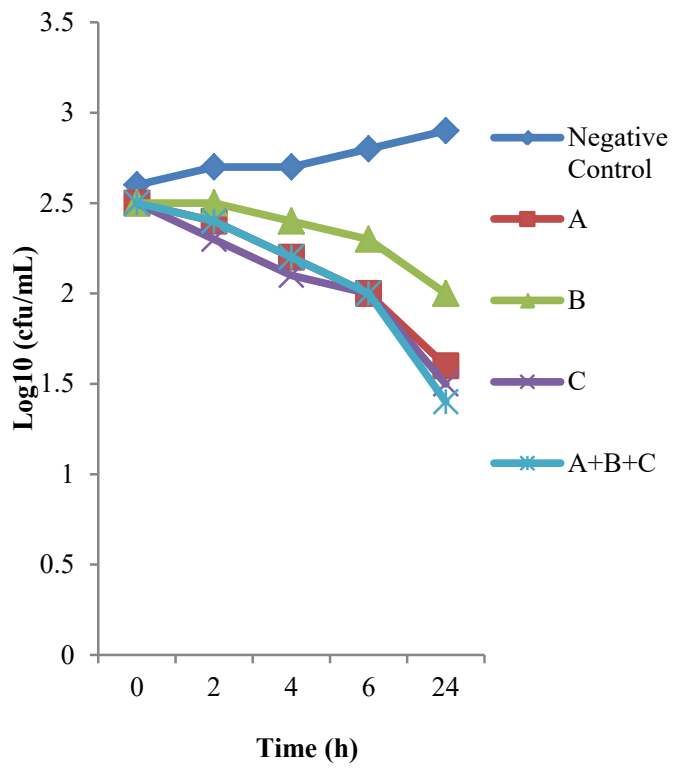

(f)

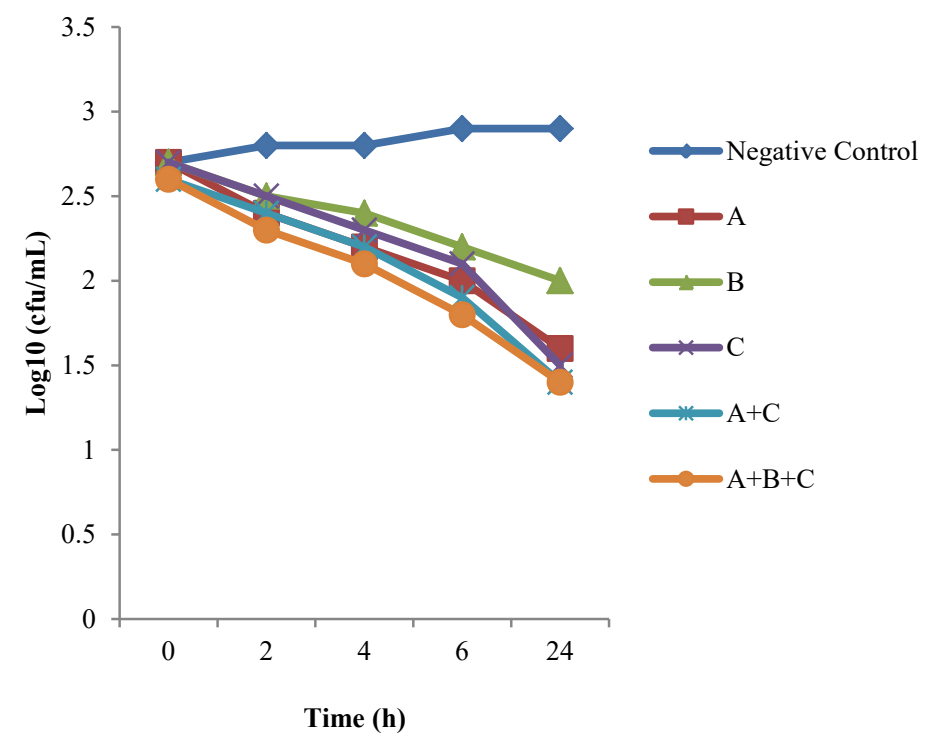

(g)

Figure 3 (a) = Killing rate of $B$. cereus by combined honey, ciprofloxacin, and $O$. gratissimum leaf acetone extract; $(\mathbf{b})=$ Killing rate of Salmonella spp by combined honey and $O$. gratissimum leaf acetone extract; (c) = Killing rate of $E$. coli by combined honey, ciprofloxacin, and $O$. gratissimum leaf acetone extract; (d) $=$ Killing rate of $P$. aeruginosa ATCC 10145 by combined honey, ciprofloxacin, and $O$. gratissimum leaf acetone extract; (e) = Killing rate of E. coli ATCC 25922 by combined honey, ciprofloxacin, and O. gratissimum leaf acetone extract; (f) = Killing rate of S. aureus NTCC 6571 by combined honey, ciprofloxacin, and $O$. gratissimum leaf acetone extract; $(\mathbf{g})=$ Killing rate of $S$. typhi ATCC 14028 by combined honey, ciprofloxacin, and $O$. gratissimum leaf acetone extract. Keys: A = acetone leaf acetone extract, $\mathrm{B}=$ honey, $\mathrm{C}=$ ciprofloxacin, Negative control = untreated organism. 


\section{Conclusions}

The information provided in this study is on the synergistic antibacterial potentials of $O$. gratissimum leaf acetone extract, honey, and ciprofloxacin on multiple drug-resistant bacteria isolated from the stool samples of diarrhea patients. These findings have revealed a high potential antibacterial activity of $O$. gratissimum leaf acetone extract, honey, and ciprofloxacin on multiple drug-resistant bacteria. Of note is the synergistic effect of $O$. gratissimum leaf acetone extract, honey, and ciprofloxacin, which showed highest antibacterial activity on the tested bacteria, thus implying its potential for use in diarrhea treatment.

\section{Acknowledgements}

The authors appreciate the pediatricians in specialist hospitals, Ondo state, and the staff of the Microbiology Laboratory, Federal University of Technology, Akure, Ondo State, Nigeria, for their support.

\section{References}

[1] JM Willey, LM Sherwood and CJ Woolverton. Prescott's microbiology. $8^{\text {th }}$ ed. New York, McGraw Hill, 2011, p. 826-9.

[2] FO Omoya and KO Ajayi. Synergistic effect of combined antibiotics against some selected multidrug resistant human pathogenic bacteria isolated from poultry droppings in Akure, Nigeria. Adv. Microbiol. 2016; 6, 1075-90.

[3] A Saini, B Singh, A Suttee, S Verma, LK Garg and S Thakur. A review on phytoconstituents: The potent synergistic approach in antimicrobial formulations. J. Pharm. Res. 2018; 12, 151-9.

[4] OO Amengialue, O Edobor and AP Egharevba. Antibacterial activity of extracts of Ocimum gratissimum on bacteria associated with diarrhea. Bayero J. Pure Appl. Sci. 2013; 6, 143-5.

[5] IU Nwankwo, CE Onwakor and OJ James. Synergistic effect of the combined ethanolic and aqueous extracts of Garcinia kola and Ocimum gratissimum on Methicillin resistant Staphylococcus aureus and multi-drug resistant Pseudomonas aeruginosa. Nat. Pharm. Tech. 2015; 5, 1-9.

[6] S Pandey. Antibacterial and antifungal activities of Ocimum gratissimum L. Int. J. Pharm. Pharm. Sci. 2017; 9, 26-31.

[7] N Namias. Honey in the management of infections. Surg. Infect. 2003; 4, 219-26.

[8] CM Nwankwo, CC Ezekoye and SO Igbokwe. Phytochemical screening and antimicrobial activity of apiary honey produced by honey bee (Apis mellifera) on clinical strains of Staphylococcus aureus, Escherichia coli and Candida albicans. Afr. J. Biotechnol. 2014; 13, 2367-72.

[9] TT Adebolu. Effect of natural honey on local isolates of diarrhea-causing bacteria in southwestern Nigeria. Afr. J. Biotechnol. 2005; 4, 1172-4.

[10] EI Chukwura and IA Iheukwumere. Determination of synergistic effect and activity index of Solenostemon monostachyus and Ocimum gratissimum on selected bacteria. Nig. J. Microbiol. 2012; 26, 2492-8.

[11] S Khan, M Imran, M Imran and N Pindari. Antimicrobial activity of various ethanolic plant extracts against pathogenic multi drug resistant Candida spp. Bioinformation 2017; 13, 67-72.

[12] MY Liu, NN Cokcetin, J Lu, L Turnbull, DA Carter, CB Whitchurch and EJ Harry. RifampicinManuka honey combinations are superior to other antibiotic-manuka combinations in eradicating Staphylococcus aureus biofilms. Front. Microbiol. 2018; 8, 1-12.

[13] A Gaurav, SP Singh, JPS Gill, R Kumar and D kumar. Isolation and identification of Shigella spp. from human fecal samples collected from Pantnagar, India. Vet. World 2013; 6, 367-79.

[14] MK Ladipo, VF Doherty and UC Kanife. Phytochemical screening and antibacterial investigation of the extract of Ocimum gratissimum (Scent leaf) on selected enterobacteriaceae. Product. Agric. Tech. 2010; 6, 75-84. 
[15] MO Ubafie and AU Ejale. Antimicrobial activity and quantitative analysis of Ocimum gratissimum on some pathogenic bacteria. Issues Bio. Sci. Pharm. Res. 2018; 6, 17-22.

[16] Clinical and Laboratory Standards Institute (CLSI). Performance standards for antimicrobial susceptibility testing: Twenty-fourth informational supplement. Clinical and Laboratory Standards Institute, Wayne, USA, 2014, p. 110-40.

[17] AI Akinyemi and AO Ogundare. Antibacterial properties of the leaf of Anthocleista djalonensis A. Chev on some pathogenic organisms. Eur. J. Med. Plants 2014; 4, 75-85.

[18] SC Onuoha. The prevalence of antibiotic resistant diarrhogenic bacterial species in surface waters, south eastern Nigeria. Ethiop. J. Health Sci. 2017; 27, 319-30.

[19] MB Odebisi-Omokanye, TO Agbabiaka, RF Zakriya and O Sanya. Antibacterial effect of Ocimum gratissimum against bacteria from paediatrics diarrhoeal stool samples in the tropics. J. Sci. Tech. 2016; 36, 64-74.

[20] JE Amadi, SO Salami and CS Eze. Antifungal properties and phytochemical screening of extracts of African Basil (Ocimum gratissimum L.) Agr. Biol. J. N. Amer. 2010; 1, 163-6.

[21] EI Nweze and EE Eze. Justification for the use of Ocimum gratissimum L. in herbal medicine and its interaction with disc antibiotics. BMC Complement. Altern. Med. 2009; 9, 31-7.

[22] O Stefanovic, L Comic, D Stanojevic and S Solujic-Sukdolak. Antibacterial activity of Aegopodium podagraria L. extracts and interaction between extracts and antibiotics. Turk. J. Biol. 2009; 33, 14550 .

[23] MK Oladunmoye, FA Akinyosoye and FC Adetuyi. Comparative studies on the amount of protein, sodium and potassium ions released by methanolic extracts from six Cassia species. Asian J. Cell Biol. 2007; 2, 29-33.

[24] KA Oyeniran, MK Oladunmoye and HO Aladeselu. Comparative studies in the release of sodium and potassium ions by indigenous black soap from selected skin pathogens. Res. J. Microbiol. 2015; 10, 592-9.

[25] MK Oladunmoye. Antioxidant, free radical scavenging capacity and antimicrobial activities of Miranilis jalapa. J. Med. Plant Res. 2012; 6, 2909-13. 